\title{
Melittin as a promising anti-protozoan peptide: current knowledge and future prospects
}

Hamed Memariani ${ }^{1,2}$ (1) and Mojtaba Memariani ${ }^{1,3^{*}}$ (i)

\begin{abstract}
Protozoan diseases such as malaria, leishmaniasis, Chagas disease, and sleeping sickness still levy a heavy toll on human lives. Deplorably, only few classes of anti-protozoan drugs have thus far been developed. The problem is further compounded by their intrinsic toxicity, emergence of drug resistance, and the lack of licensed vaccines. Thus, there is a genuine exigency to develop novel anti-protozoan medications. Over the past years, melittin, the major constituent in the venom of European honeybee Apis mellifera, has gathered the attention of researchers due to its potential therapeutic applications. Insofar as we are aware, there has been no review pertinent to anti-protozoan properties of melittin. The present review outlines the current knowledge about anti-protozoan effects of melittin and its underlying mechanisms. The peptide has proven to be efficacious in killing different protozoan parasites such as Leishmania, Plasmodium, Toxoplasma, and Trypanosoma in vitro. Apart from direct membrane-disruptive activity, melittin is capable of destabilizing calcium homeostasis, reducing mitochondrial membrane potential, disorganizing kinetoplast DNA, instigating apoptotic cell death, and induction of autophagy in protozoan pathogens. Emerging evidence suggests that melittin is a promising candidate for future vaccine adjuvants. Transmission-blocking activity of melittin against vector-borne pathogens underscores its potential utility for both transgenic and paratransgenic manipulations. Nevertheless, future research should focus upon investigating anti-microbial activities of melittin, alone or in combination with the current anti-protozoan medications, against a far broader spectrum of protozoan parasites as well as pre-clinical testing of the peptide in animal models.
\end{abstract}

Keywords: Melittin, Anti-protozoan effects, Leishmania, Plasmodium, Trypanosoma

\section{Keypoints}

- Melittin targets cell membrane and intracellular components of protozoan pathogens.

- Due to adjuvant properties of melittin, it has the potentiality for developing anti-leishmania vaccine.

- Transgenic mosquitoes expressing melittin may offer opportunities for controlling malaria.

\footnotetext{
*Correspondence: memaryani@gmail.com

${ }^{1}$ Skin Research Center, Shahid Beheshti University of Medical Sciences, Tehran, Iran

Full list of author information is available at the end of the article
}

\section{Introduction}

Protozoan infections imperil the lives of almost one-third of the world's population. Malaria, visceral leishmaniasis (kala-azar), Chagas disease (American trypanosomiasis), and sleeping sickness (African trypanosomiasis) still remain as dreadful scourges to mankind, particularly in tropical and sub-tropical regions (Sbaraglini et al. 2016; Norman et al. 2020). Protozoans are a diverse, polyphyletic group of heterotrophic unicellular eukaryotic organisms (Karpiyevich and Artavanis-Tsakonas 2020). In view of the fact that they share many metabolic pathways with their mammalian hosts, drug development against these pathogens has long been an excruciating task for pharmaceutical industry. For this reason, only a handful of
Springer Open (c) The Author(s) 2021. This article is licensed under a Creative Commons Attribution 4.0 International License, which permits use, sharing, adaptation, distribution and reproduction in any medium or format, as long as you give appropriate credit to the original author(s) and the source, provide a link to the Creative Commons licence, and indicate if changes were made. The images or other third party material in this article are included in the article's Creative Commons licence, unless indicated otherwise in a credit line to the material. If material is not included in the article's Creative Commons licence and your intended use is not permitted by statutory regulation or exceeds the permitted use, you will need to obtain permission directly from the copyright holder. To view a copy of this licence, visit http://creativeco mmons.org/licenses/by/4.0/. 
new medications with anti-protozoal activities have come on the market over the course of past decades (Müller and Hemphill 2016). The problem is further exacerbated by their intrinsic toxicity, emergence of drug resistance, ineffective vector control interventions, and the lack of licensed vaccines (Capela et al. 2019). To truly address these encumbrances, innovative approaches and frugal solutions are required. Perhaps counter-intuitively, animal venoms could serve as an untapped source of novel anti-microbial drug candidates (Memariani and Memariani 2020).

Since antiquity, various honeybee products including honey, royal jelly, beeswax, propolis, bee pollen, and bee venom have been exploited for not only nutritional purposes, but also curative intentions (Cornara et al. 2017; Duffy et al. 2020). Bees are armed with stings and potent venoms to fend off intruders (Walker et al. 2020). The venom of European honeybee (Apis mellifera) is replete with a complex farrago of biologically active substances such as peptides, enzymes, and amines (Dotimas and Hider 1987). Honeybee venom has been extensively used as a traditional anti-inflammatory remedy for a myriad of illnesses such as dermatological maladies (Kim et al. 2019), multiple sclerosis (Hauser et al. 2001), rheumatoid arthritis (Lee et al. 2014), and chronic pains (Seo et al. 2017), though the precise mechanism of action at the cellular level has not been fully realized so far.

Prominent among the honeybee venom components is melittin, an amphipathic hexacosapeptide, which makes up around half of the dry weight (Maulet et al. 1982). Despite having a conspicuously hydrophobic amino acid composition, melittin represents a net charge of +6 at physiological $\mathrm{pH}$ due to the existence of lysine and arginine residues (Dempsey 1990). In an aqueous solution of low concentration and low ionic strength, the peptide displays a random coil conformation (Vogel 1981). It assumes an $\alpha$-helical structure in the presence of various detergent molecules or lipid membranes (Knöppel et al. 1979; Lauterwein et al. 1979). Melittin is thought to be monomeric at low peptide concentration, while it is associated as a tetrameric aggregate under certain conditions such as high salt concentration and/or high pH (Hall et al. 2011). Another feature of melittin is its ability to induce pore formation in natural and artificial lipid membranes (van den Bogaart et al. 2008). This membrane-disruptive activity of melittin may culminate in cell lysis (Memariani et al. 2020a). Further explanations concerning all features of melittin are beyond the scope of this review. Therefore, we refer interested readers to other thorough publications (Raghuraman and Chattopadhyay 2007; Carpena et al. 2020; Hong et al. 2019).

As far back as the early 1950s, the existence of melittin in the honeybee venom became apparent when the direct hemolysin was electrophoretically separated from the indirect hemolysin phospholipase A (Neumann et al. 1952; Habermann 1972). The first fundamental investigation on anti-microbial properties of melittin was carried out by Fennell et al. (1967), who reported that a penicillin-resistant isolate of Staphylococcus aureus was susceptible to bee venom and its melittin fraction. It was not until the late 1980s that melittin was shown to be cytotoxic to trypanosomatid protozoan parasites (Azambuja et al. 1989). In particular, the past two decades have witnessed a good deal of interest on biological effects and modes of action of melittin against different protozoan parasites. The therapeutic potentiality of melittin has also been emphasized repeatedly in recent years.

Insofar as we are aware, no review has discussed the anti-protozoan activities of melittin and its underlying mechanisms. This compendious review is thus the first endeavor to synopsize the literature available on the subject. For this purpose, literature searches with PubMed and Google Scholar using words [melittin] and [protozoa] or [antiprotozoal activity] or [Leishmania] or [Plasmodium] or [Toxoplasma] or [Trypanosoma] for published English-language papers from inception until the end of 2020 were carried out by the authors. For the sake of readers' convenience, a brief description of relevant pathogens is given at the outset of each section.

\section{Anti-protozoan properties of melittin}

\section{Leishmania spp.}

Leishmaniasis is a sandfly-transmitted disease caused by obligate intracellular parasite of the genus Leishmania (Roatt et al. 2020). The dimorphic life-cycle of Leishmania relies upon continuous shuttling between an invertebrate vector and a mammalian host. Within the digestive tract of sandfly, the pathogen exists as extracellular flagellated promastigotes. Contrariwise, intracellular nonmotile amastigotes survive and proliferate inside host's phagocytes (Steverding 2017). Given that different species of Leishmania are morphologically indiscernible, a variety of techniques based on molecular methods, isoenzyme analysis, or monoclonal antibodies have so far been developed for the differentiation of the pathogenic species (Thakur et al. 2020). The clinical manifestations of leishmaniasis are not only dependent on the species of the pathogen, but also on the immunological status and genetically determined responses of patients. These range from self-resolving cutaneous ulcers to mutilating mucocutaneous lesions and even to severe, life-menacing visceral infections. In this respect, L. major and L. trop$i c a$ are the main dermotropic species, whereas visceral leishmaniasis is predominantly caused by $L$. donovani or L. infantum (Roatt et al. 2020). It has been stated that 
roughly 1.5 to 2 million new cases of leishmaniasis occur annually, of whom 70,000 perished as a result of complications (Torres-Guerrero et al. 2017). Pentavalent antimonials are still considered as the first line of treatment for various forms of leishmaniasis, though other new medications including amphotericin B (in deoxycholate or liposomal formulations), miltefosine, and paromomycin are now available (Roatt et al. 2020). These therapies have certain detrimental effects or pharmacological liabilities that may cause treatment failure or relapse of the disease (Roatt et al. 2020).

The half lethal dose $\left(\mathrm{LD}_{50}\right)$ of melittin towards L. donovani $\left(2 \times 10^{7}\right.$ promastigote/mL $)$ has been estimated to be $0.3 \mu \mathrm{M}$, as determined by 3-(4,5-dimethylthiazol-2-yl)2,5-diphenyltetrazolium bromide (MTT) assay (DíazAchirica et al. 1998). Intriguingly, a lower concentration of melittin $(0.2 \mu \mathrm{M})$ was found to be sufficient to raise intracellular concentration of free calcium $\left(\left[\mathrm{Ca}^{2+}\right] \mathrm{i}\right)$ from 100 to around $440 \mathrm{nM}$ when the $L$. donovani promastigotes were suspended in medium comprising $2 \mathrm{mM}$ $\mathrm{CaCl}_{2}$ (Catisti et al. 2000). In addition, a dose-dependent enhancement of $\left[\mathrm{Ca}^{2+}\right] \mathrm{i}$ in promastigotes was reported at melittin concentrations ranging from 0.1 to $0.5 \mu \mathrm{M}$. Other species of Leishmania have also been surveyed for their vulnerability to melittin treatment (Table 1). According to a study conducted by Pereira et al. (2016), the concentration of melittin yielding half-maximal inhibition $\left(\mathrm{IC}_{50}\right)$ of promastigotes and intracellular amastigotes of $L$. infantum were 28.29 and $1.40 \mu \mathrm{g} / \mathrm{mL}$, respectively. In the case of $L$. major $\left(2 \times 10^{6}\right.$ promastigotes $\left./ \mathrm{mL}\right)$, the median effective concentration $\left(\mathrm{EC}_{50}\right)$ of melittin, representing a peptide concentration for inducing cell death in $50 \%$ of the treated parasites, was found to be $74.01 \pm 1.27 \mu \mathrm{g} /$ $\mathrm{mL}$. Nevertheless, melittin concentrations up to $100 \mu \mathrm{g} /$ $\mathrm{mL}$ were not adequate to reach the $\mathrm{EC}_{50}$ against $L$. panamensis promastigotes (Pérez-Cordero et al. 2011). These results point out that $L$. panamensis promastigotes are more resistance to melittin exposure as compared with L. major promastigotes in vitro. One study also revealed that the concentration required to diminish the infection rate of internalized L. panamensis amastigotes by $50 \%$ $\left(\mathrm{EC}_{50} \mathrm{i}\right)$ was greater or equal to $10 \mu \mathrm{g} / \mathrm{mL}$ (Pérez-Cordero et al. 2011).

Cytotoxicity assays provide a crucial means for safety assessment and screening in drug development (Fumarola et al. 2004). Various host cells have hitherto been subjected to different melittin concentrations. For instance, a 24-h incubation of immature human dendritic cells $\left(10^{5}\right.$ cells $\left./ \mathrm{mL}\right)$ with melittin has unveiled a median lethal concentration $\left(\mathrm{LC}_{50}\right)$ of $43.42 \pm 0.86 \mu \mathrm{g} / \mathrm{mL}$. A median hemolytic concentration $\left(\mathrm{HC}_{50}\right)$ of $16.28 \pm 0.17 \mu \mathrm{g} / \mathrm{mL}$ against human red blood cells ( $2 \%$ suspension) was also reported for the peptide (Pérez-Cordero et al. 2011).
As regards mouse peritoneal macrophages (MPMs), an $\mathrm{IC}_{50}$ value of $5.73 \mu \mathrm{g} / \mathrm{mL}$ was obtained for melittin after $48 \mathrm{~h}$. Despite complete eradication of L. infantum amastigotes, $2.5 \mu \mathrm{g} / \mathrm{mL}$ of melittin induced some morphological changes in MPMs (Pereira et al. 2016). Keep in mind that selective toxicity is a crucial feature of antimicrobial agents. It refers to a substance that is only toxic to a specified microorganism while inflicting minimal or no harm on the host cells (Bacalum and Radu 2015). Indeed, this can be assessed using selectivity index (SI), which is indicative of the therapeutic window of an antimicrobial agent. The higher the SI, the greater the difference between adverse effects and favorable anti-infective properties (Memariani et al. 2018). Comparing the toxic effects of melittin on MPMs with L. infantum amastigotes disclosed a SI value of 4 (Pereira et al. 2016). In other words, the cytotoxic activity of melittin against $L$. infantum is four times as high as that of the mammalian cells. Contrary to expectations, the SI value of $\leq 1$ was shown for $L$. panamensis amastigotes and immature human dendritic cells, which was not satisfactory (Pérez-Cordero et al. 2011).

Macrophages are considered as pivotal host cells for Leishmania proliferation and elimination. Leishmania survival and persistence within the macrophages are known to be dependent upon several factors such as the species of the pathogen, type, and magnitude of the host immune responses (Tomiotto-Pellissier et al. 2018; Van Assche et al. 2011). Hence, proper activation of macrophages is an indispensable requirement for intracellular obliteration of Leishmania. Along with direct inhibitory effects, melittin seems to attenuate Leishmania infectivity through modulation of immune responses. Melittin influences the levels of anti-inflammatory [interleukin-10 (IL-10) and transforming growth factor- $\beta$ (TGF- $\beta$ )] and pro-inflammatory cytokines [interleukin-12 (IL-12) and tumor necrosis factor- $\alpha$ (TNF- $\alpha$ )] in vitro (Pereira et al. 2016). Noticeably, non-toxic doses of melittin was shown to augment IL-12 production in macrophages infected with $L$. infantum. IL-12 is believed to be necessary for the development of protective T-helper 1 (Th1)-predominant immunity as well as controlling the Leishmania proliferation (Okwor and Uzonna 2016; von Stebut et al. 1998). By virtue of the fact that IL-12 has the potential to act as an adjuvant in Leishmania vaccines (Scott and Trinchieri, 1997; Mutiso et al. 2010), melittin could be used in vaccine formulations to boost immune responses against leishmaniasis.

According to the work of Pereira et al. (2016), exposure of infected macrophages to melittin $(2.5 \mu \mathrm{g} / \mathrm{mL})$ for 24 , 48 , and $72 \mathrm{~h}$ resulted in a significant reduction in TNF- $\alpha$ levels compared to untreated infected macrophages $(p<0.05)$. Although TNF- $\alpha$ contributes to Leishmania 


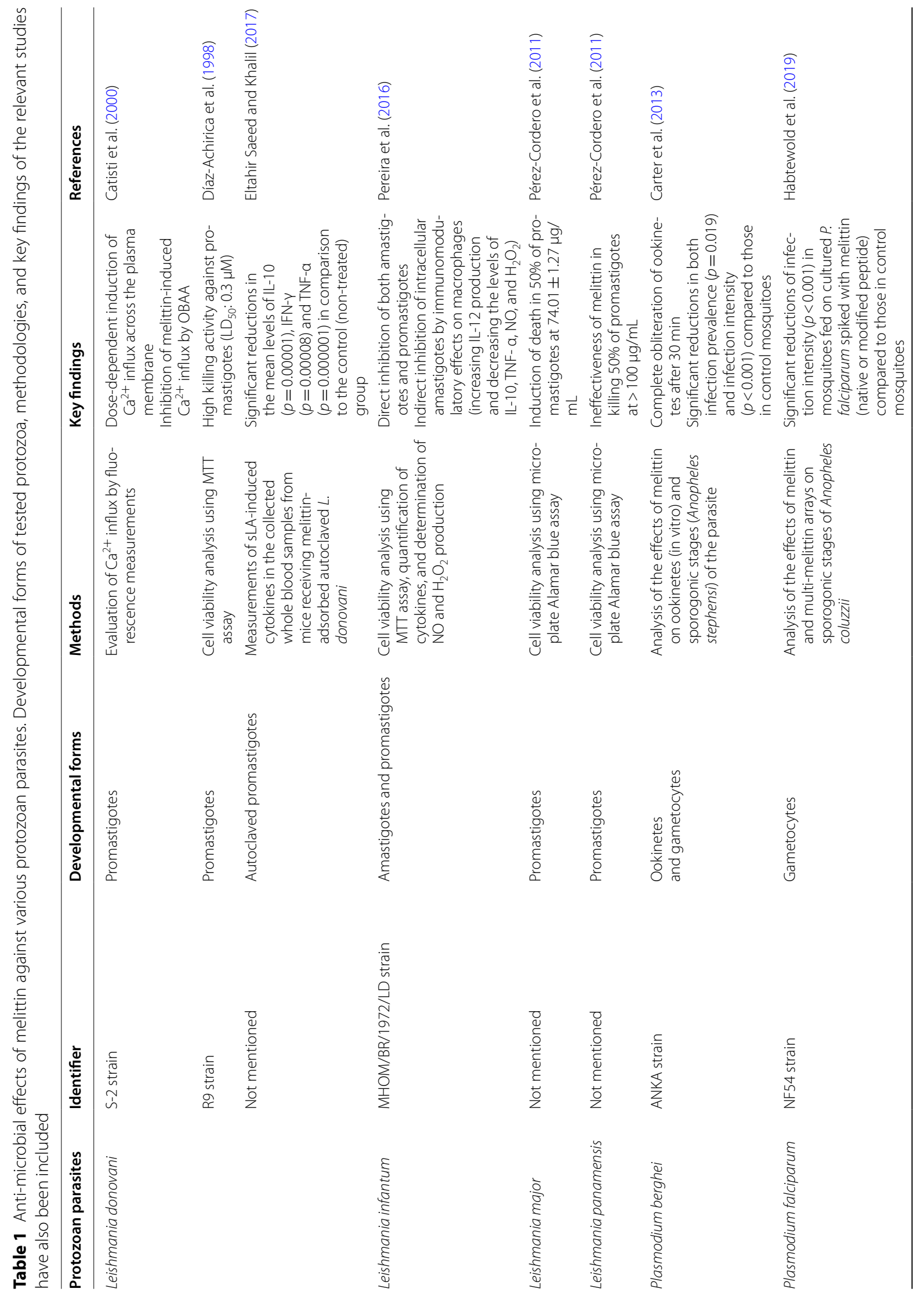




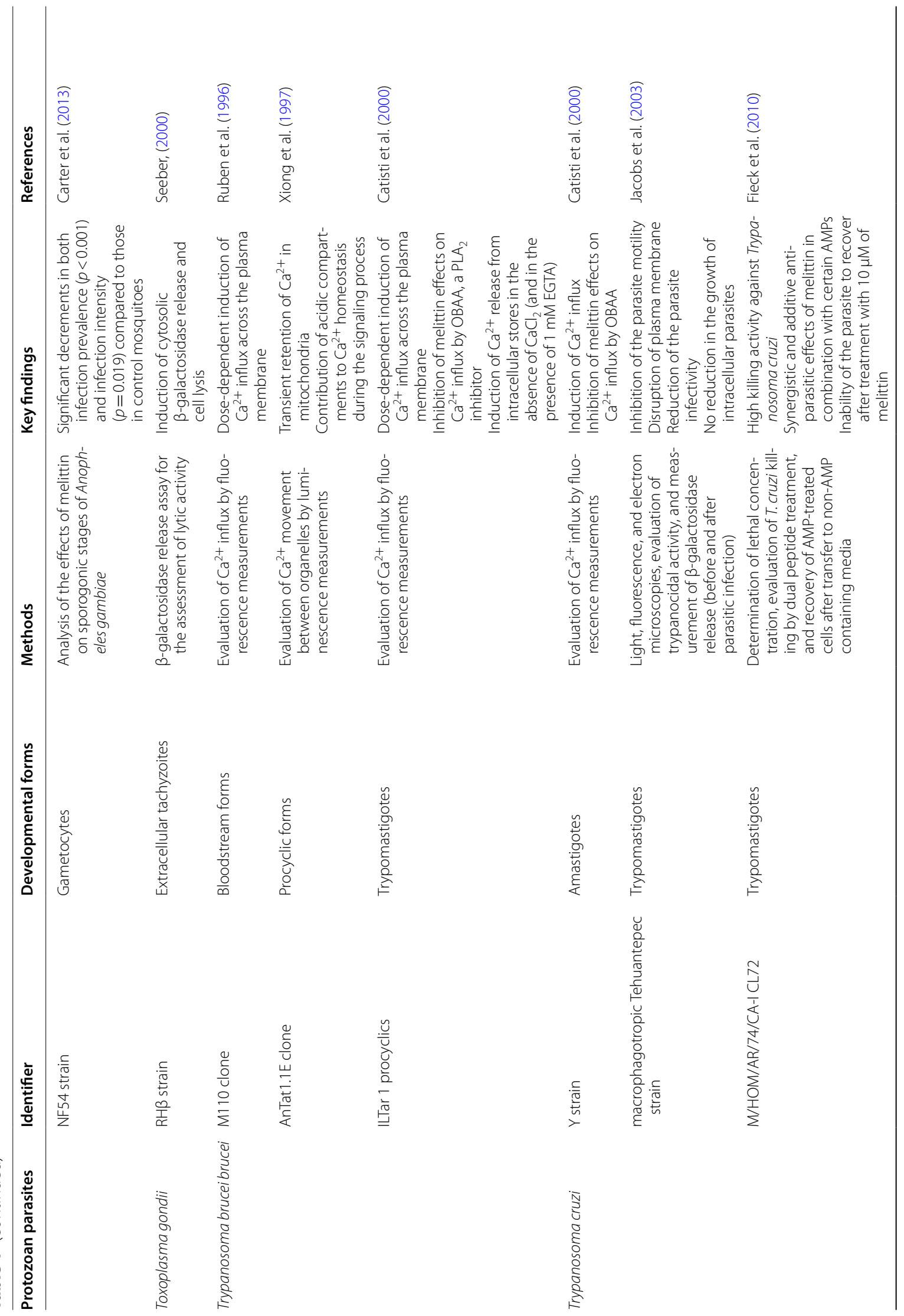




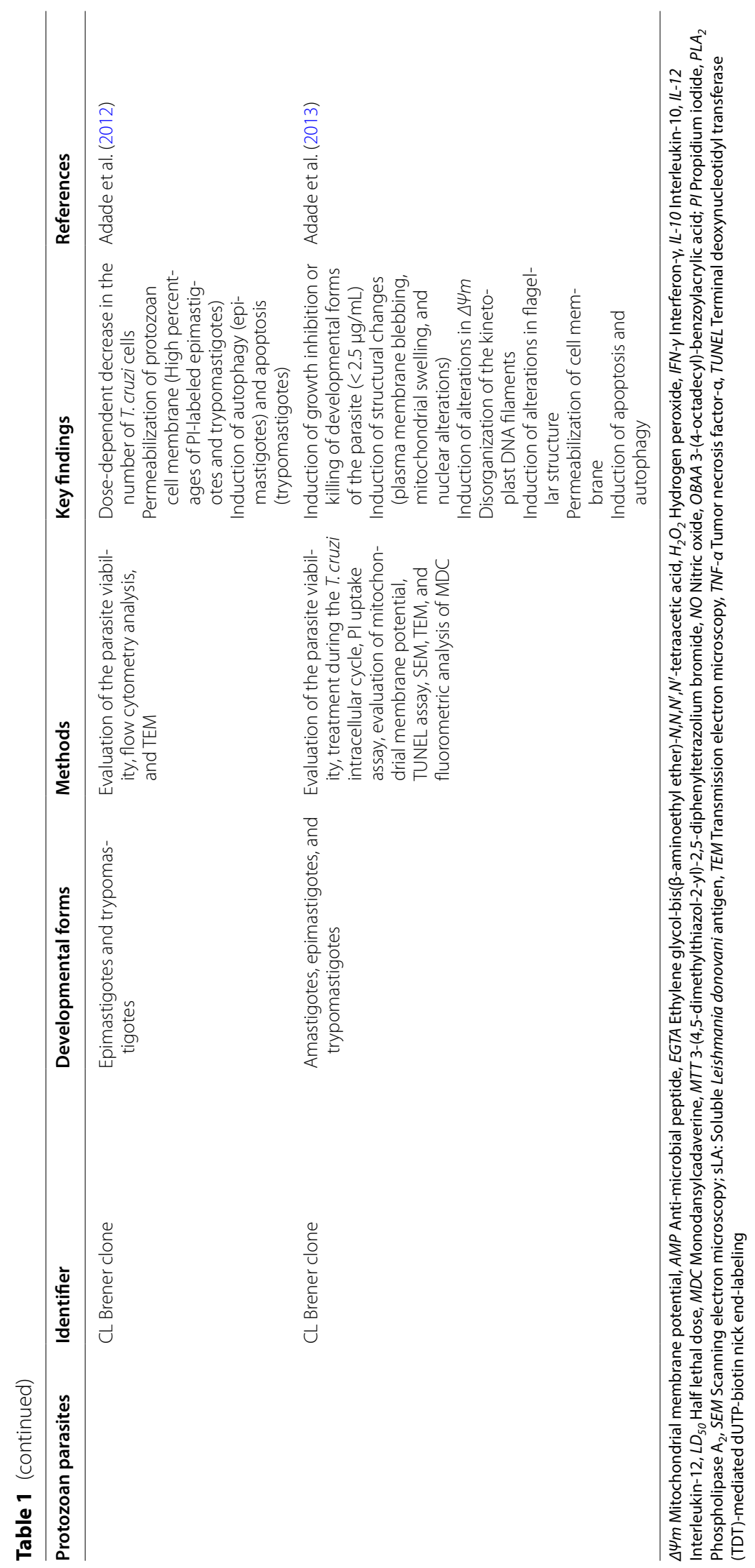


clearance by enhancing macrophage activity and nitric oxide (NO) synthesis (Mirzaei et al. 2020), Pereira et al. (2016), however, were of the opinion that melittin-mediated downregulation of TNF- $\alpha$ might be beneficial in mitigating untoward effects of TNF- $\alpha$ excess. Beside this, a notable drop in IL-10 levels was evident in the melittin-treated infected macrophages (Pereira et al. 2016). Considering the role of IL-10 in macrophage deactivation and parasite persistence (Kane and Mosser, 2001; Mirzaei et al. 2020), reduction of IL-10 levels by melittin might thwart the disease progression. By contrast, when the infected macrophages were challenged with different doses of melittin, no variation was observed in TGF- $\beta$ levels. In comparison to the untreated infected macrophages, incubation of the infected macrophages with melittin caused significant diminution in the levels of $\mathrm{NO}$ and hydrogen peroxide $\left(\mathrm{H}_{2} \mathrm{O}_{2}\right)(p<0.05)$. These results suggest that the eradication of intracellular amastigotes by melittin might occur in a $\mathrm{H}_{2} \mathrm{O}_{2}$ - and NO-independent mechanism (Pereira et al. 2016).

In a study conducted by Eltahir Saeed and Khalil (2017), Swiss CD1 mice were injected with three intradermal doses of melittin-adsorbed autoclaved L. donovani (ALD). The collected whole blood samples from these mice were then stimulated with soluble $L$. donovani antigen (sLA), after which the mean levels of some cytokines in cell supernatants were measured. Interestingly, the mean levels of sLA-induced IL-10, Interferon- $\gamma$ (IFN- $\gamma$ ), and TNF- $\alpha$ were found to be substantially greater in the blood samples of aforementioned mice than those of the control (non-treated) group (Eltahir Saeed and Khalil 2017). The observation that melittin reduces IL-10 levels is consistent with the earlier findings by Pereira et al. (2016). Based on these results, the conclusion was drawn that melittin could modulate both Th1 and Th2 immune responses in Swiss CD1 mice (Eltahir Saeed and Khalil 2017). Taken together, melittin-adsorbed autoclaved Leishmania has the potentiality for developing anti-leishmania vaccine.

\section{Trypanosoma brucei}

Similar to Leishmania, Trypanosoma is a genus of kinetoplastids, a group of unicellular flagellated eukaryotes related to the euglenids (Stuart et al. 2008). Human African trypanosomiasis (HAT) or sleeping sickness is a deadly insect-borne disease that flourishes in impoverished, rural parts of sub-Saharan Africa, where it is transmitted by the bite of tsetse fly (Bukachi et al. 2018). Two sub-species of Trypanosoma brucei are responsible for the disease in humans. Trypanosoma brucei gambiense gives rise to slow-onset chronic illness in western and central Africa, whereas Trypanosoma brucei rhodesiense is associated with a more acute form of HAT in southern and eastern Africa. The third subspecies Trypanosoma brucei brucei is a causative agent of animal trypanosomiasis, and does not infect humans (Malvy and Chappuis 2011). Trypanosomes are shrouded in a variant surface glycoprotein coat, helping them to escape the host immune reactions. Owing to the sophisticated and evasive nature of the pathogen, vaccination against T. bru$c e i$ has been futile (Black and Mansfield 2016). Thus far, only four medications are registered for the treatment of early- and late-stage HAT: pentamidine, suramin, melarsoprol, and eflornithine. Although nifurtimox is not approved for chemotherapy, it has been used in combination with eflornithine for the second stage of HAT due to T.b. gambiense (Malvy and Chappuis 2011).

During the late 1990s, a number of studies provided compelling evidence that melittin rises $\left[\mathrm{Ca}^{2+}\right] \mathrm{i}$ in $T$. b. brucei (Ruben et al. 1996; Xiong et al. 1997; Ridgley et al. 1999). The initial indication of melittin-induced $\mathrm{Ca}^{2+}$ influx across the parasite plasma membrane came from two different experiments which were undertaken by Ruben et al. (1996). In the first experiment, melittin had no impact on $\left[\mathrm{Ca}^{2+}\right] \mathrm{i}$ in a buffered salt solution comprising $3 \mathrm{mM}$ ethylene glycol-bis( $\beta$-aminoethyl ether)$N, N, N^{\prime}, N^{\prime}$-tetraacetic acid (EGTA; for chelating the extracellular $\mathrm{Ca}^{2+}$ ). The peptide, however, caused an elevation of $\left[\mathrm{Ca}^{2+}\right] \mathrm{i}$ in the same solution containing $2 \mathrm{mM}$ $\mathrm{Ca}^{2+}$. Further evidence in support of this observation was gained through $\mathrm{Mn}^{2+}$ quench experiments on T. b. brucei cells loaded with calcium-sensitive dye Fura-2. Analogous findings relative to the melittin-induced $\mathrm{Ca}^{2+}$ influx in T. b. brucei cells were described by Catisti et al. (2000). Plasma membrane-located $\mathrm{Ca}^{2+}$ channels, but not permeabilized plasma membrane, appeared to be contributing to the aforesaid $\mathrm{Ca}^{2+}$ influx (Ruben et al. 1996). The enthused readers ought to consult the original paper for further details (Ruben et al. 1996).

A subsequent study by Xiong et al. (1997) extended the above-mentioned findings to indicate that most of the $\mathrm{Ca}^{2+}$, which were entered the cell across the plasma membrane or were liberated from the acidocalcisome, transiently accumulated into mitochondria during the signaling process induced by melittin. In another investigation, melittin $(200 \mathrm{nM})$ was shown to impair the $\mathrm{Ca}^{2+}$ transport properties of the mitochondria (Ridgley et al. 1999). In response to melittin, the acidocalcisome thought to be involved in maintaining $\mathrm{Ca}^{2+}$ homeostasis (Xiong et al. 1997). These findings were further confirmed by a study in which exposure of $T . b$. bru$c e i$ procyclic trypomastigotes to melittin in $\mathrm{Ca}^{2+}$-free medium led to an appreciable increase in $\left[\mathrm{Ca}^{2+}\right] \mathrm{i}$ (Catisti et al. 2000). This highlights the probable role of intracellular $\mathrm{Ca}^{2+}$ stores such as the acidocalcisomes in $\mathrm{Ca}^{2+}$ mobilization. Considering the destabilization effects of 
melittin on $\left[\mathrm{Ca}^{2+}\right] \mathrm{i}$ in $\mathrm{T}$. brucei cells, it will be of interest to utilize melittin and other anti-trypanosomatid drugs acting on $\mathrm{Ca}^{2+}$ homeostasis concurrently to comprehend if synergism occurs.

Hydrolysis of phosphatidylinositol-4,5-bisphosphate by phospholipase $C$ yields inositol-1,4,5-trisphosphate $\left(\mathrm{IP}_{3}\right)$ and diacylglycerol, both of which act as second messengers in eukaryotic signal transduction pathways (Cestari 2020; de Paulo Martins et al. 2010). The former prompts $\mathrm{Ca}^{2+}$ release from intracellular stores, while the latter activates protein kinase C (Catisti et al. 2000). Ruben et al. (1996) quantitated $\mathrm{IP}_{3}$ in control and melittin-treated $T . b$. brucei cells individually. They found no substantial changes in the resting levels of $\mathrm{IP}_{3}$ after 30-s or 2-min exposure of $T$. $b$. brucei cells to melittin. Their conclusion was that the trypanosomal calcium influx induced by melittin appeared to be independent of $\mathrm{IP}_{3}$ involvement. Furthermore, the effect of melittin on $\left[\mathrm{Ca}^{2+}\right] \mathrm{i}$ could be mediated by a phospholipase $\mathrm{A}_{2}\left(\mathrm{PLA}_{2}\right)$ activation (Catisti et al. 2000). In support of this, it was shown that melittin-induced $\mathrm{Ca}^{2+}$ influx in procyclic trypomastigotes of $T . b$. brucei was inhibited using $5 \mu \mathrm{M}$ of 3-(4-octadecyl)-benzoylacrylic acid (OBAA), a PLA 2 inhibitor (Catisti et al. 2000).

It has been demonstrated that mammalian cells are less vulnerable to melittin treatment in comparison with T. $b$. brucei. In this respect, the dose at which the parasite gave a response was 5-20 times lower than that of mammalian cells (Ruben et al. 1996). The reason for this observation is as yet unclear, but it might be attributable to some differences between $\mathrm{Ca}^{2+}$ channels, contributing to intracellular $\mathrm{Ca}^{2+}$ homeostasis, in mammalian and $T$. b. brucei cells. Indeed, $\mathrm{Ca}^{2+}$ plays a pivotal part in regulation of multiple biological processes in trypanosomes such as invasion, cellular differentiation, and flagellar movements, to cite only a few (Benaim et al. 2020; Smirlis et al. 2010). In light of the fact that melittin induces $\left[\mathrm{Ca}^{2+}\right]$ i disturbance in $T$. brucei cells, it would be desirable to assess whether or not the peptide affects abovementioned processes.

\section{Trypanosoma cruzi}

Trypanosoma cruzi is the causative agent of Chagas disease, which is largely confined to endemic regions of Latin American countries (Harrison et al. 2020). Contamination of the bite site or intact mucous membranes by infected triatomine bug feces is the primary route of transmission (Bern 2015). Other less common routes of transmission include blood transfusions, organ transplantation, and transplacental transmission. If the disease progresses to the chronic phase, serious complications such as congestive heart failure, esophageal dilatation, and enlargement of colon may occur (Bern 2015).
Benznidazole and nifurtimox are the only medications with proven efficacy against Chagas disease; however, both drugs exhibit significant adverse effects and low effectiveness in adults with chronic infections (Villalta and Rachakonda 2019).

There are multiple lines of evidence affirming the anti-parasitic effects of melittin upon T. cruzi (Table 1). For instance, $\mathrm{IC}_{50}$ of $T$. cruzi epimastigotes was $2.44 \pm 0.23 \mu \mathrm{g} / \mathrm{mL}$ after a single day of incubation with melittin, while this value was much lower $(0.22 \pm 0.09 \mu \mathrm{g} /$ $\mathrm{mL}$ ) for intracellular amastigote (Adade et al. 2013). Using light microscopy, melittin $(2.5 \mu \mathrm{M})$ was shown to cease the motility of at least $50 \%$ of T. cruzi after $30 \mathrm{~min}$ of incubation (Jacobs et al. 2003). This event might result from alterations in flagellar structure and/or direct lethal activity of melittin. In connection with the former, melittin was shown to induce multiple morphological abnormalities in flagella such as swelling in some region of the flagellum, formation of cracks, and blebbing of flagellar membrane (Adade et al. 2013). Moreover, some authors have pointed out that melittin possesses lethal activity against T. cruzi in vitro (Fieck et al. 2010; Adade et al. 2012, 2013). For example, Fieck et al. (2010) demonstrated that melittin had a lethal concentration $\left(\mathrm{LD}_{100}\right)$ of $30 \mu \mathrm{M}$ towards T. cruzi after $96 \mathrm{~h}$.

The most frequent cell lines that have been exploited as host cells for T. cruzi studies are Vero (African green monkey renal epithelial cells), LLC-MK2 (Rhesus monkey kidney epithelial cells), peripheral blood mononuclear cells (PBMCs), and human placenta derivatives (Duran-Rehbein et al. 2014). Neither un-infected LLCMK2 cells nor un-infected mouse peritoneal macrophages were found to be cytotoxically affected by $1 \mu \mathrm{g} /$ $\mathrm{mL}$ of melittin after $24 \mathrm{~h}$. In LLC-MK2 cells, however, increasing melittin concentration to $5 \mu \mathrm{g} / \mathrm{mL}$ led to $49 \%$ cell death (Adade et al. 2013). The selectivity indices of melittin, measured by the ratio between the peptide toxicity to LLC-MK2 and parasite cells, were calculated to be 2.05, 35.7, 22.7 for epimastigotes, trypomastigotes, and intracellular amastigotes, respectively (Adade et al. 2013). From this finding, epimastigotes appear to be more efficiently inhibited by melittin in comparison with trypomastigotes and intracellular amastigotes. Nevertheless, all three developmental forms of T. cruzi can be inhibited/killed by melittin more selectively than the host cells. The observed selective toxicity might be ascribed to the inherent differences between biomembrane lipid compositions of the host cells and the parasite, in particular different quantities of total phospholipids and sterols (Souza et al. 2016). In one study, pre-incubation of $T$. cruzi with as low as $1 \mu \mathrm{M}$ melittin considerably curtailed the ability of parasite to infect human glioblastoma cell line 86HG39 (Jacobs et al. 2003). In spite of this, 
melittin failed to abolish intracellular growth of $T$. cruzi in infected 86HG39 cells after $24 \mathrm{~h}$ (Jacobs et al. 2003).

It appears as though programmed cell death (PCD) plays a role in the control of proliferation and differentiation in trypanosomatids (Piacenza et al. 2007; Lee et al. 2002). PCD has been characterized on the basis of morphological criteria and environmental conditions. This process can be categorized into three distinct types, namely apoptosis (type I PCD), autophagy (type II PCD), and programmed necrosis (type III PCD) (Kroemer et al. 2009; Adade et al. 2013). In trypanosomatids, a wide range of stress conditions such as anti-protozoal drugs and nutrient depletion were proved to be involved in autophagy (Menna-Barreto 2019). In 2012, Adade et al. (2012) were the first to declare that melittin instigated dissimilar PCD pathways in epimastigotes and trypomastigotes at concentrations that were non-toxic for peritoneal macrophages. In this sense, autophagy and apoptosis appeared to be the frequent causes of cell death in epimastigotes and trypomastigotes, respectively. Shortly thereafter, these investigators (Adade et al. 2013) succeeded in affording more details upon the lethal effects of melittin towards all T. cruzi developmental forms (Table 1). Some ultrastructure alternations in the melittin-treated epimastigotes involve mitochondrial swelling and the appearance of endoplasmic reticulum profiles around various organelles (resembling autophagy), which were analogous to those observed in melittin-treated amastigotes. In the case of trypomastigotes, melittin was shown to induce mitochondrial swelling, kinetoplast DNA (kDNA) disorganization, and nuclear apoptotic changes (Adade et al. 2013).

Terminal deoxynucleotidyl transferase (TDT)-mediated dUTP-biotin nick end-labeling (TUNEL) assay is a technique for detection of DNA fragmentation in apoptotic cells (Kyrylkova et al. 2012). For staining of autophagic vacuoles, an autofluorescent lysosomotropic substance named monodansylcadaverine (MDC) is commonly used (Biederbick et al. 1995). Using TUNEL assay and MDC labeling of T. cruzi, Adede et al. (2013) were able to further substantiated differences in PCD pathways of melittin-treated epimastigotes and trypomastigotes. Contrary to melittin-treated epimastigotes, DNA fragmentation was more pronounced in melittin-treated trypomastigotes, which is reminiscent of an apoptosis-like death. However, exposure to melittin caused a significantly higher MDC fluorescence intensity in epimastigotes compared to trypomastigotes $(p \leq 0.05)$, indicating a predominance of autophagic-like cell death in epimastigotes (Adade et al. 2013).

In a study conducted by Jacobs et al. (2003), treatment of $\beta$-galactosidase-expressing trypomastigotes with $5 \mu \mathrm{M}$ melittin evoked $\beta$-galactosidase release into the supernatant, particularly after $15 \mathrm{~min}$. The same authors further noted that melittin brought about a total disruption of the parasite plasma membrane. In accordance with this observation, a 1-day melittin treatment of epimastigotes $\left(\mathrm{IC}_{50}\right)$ or trypomastigotes $\left(\mathrm{LD}_{50}\right)$ resulted in a marked increase in the number of propidium iodide (PI)-labled cells (Adade et al. 2013). PI is an intercalating DNA-binding dye, and is indeed capable of entering and staining cells having compromised membrane integrity (Memariani et al. 2020b). Apart from disrupting cell membrane integrity, melittin may reduce mitochondrial membrane potential $(\Delta \Psi m)$ (Adade et al. 2013).

Melittin can act synergistically or additively with certain AMPs to eradicate T. cruzi cells in vitro. When used in paired treatments, melittin in combination with magainin II exhibited synergistic interactions. Other AMPs such as apidaecin and cecropin A had additive effects. T. cruzi cells subjected to these treatments were unable to recover after transfer to AMP-free media for $96 \mathrm{~h}$ (Fieck et al. 2010), attesting to the potential utility of melittin-AMP mixtures as efficacious trypanocidal agents. Curiously, $\mathrm{LD}_{100}$ value for melittin against $T$. cruzi was 2.6 times as low as the minimal bactericidal concentration for Rhodococcus rhodnii, an obligate symbiotic bacterium in the midgut of Chagas disease vector Rhodnius prolixus (Fieck et al. 2010). Based on these findings, melittin, either alone or combined with other effector molecules, would seem to be a propitious candidate for future paratransgenic systems to control transmission of Chagas disease.

\section{Plasmodium spp.}

The phylum Apicomplexa constitutes an extremely large and diverse group of obligatory parasites, which has developed extraordinary adaptations for invading and surviving within their hosts (Suarez et al. 2019). Plasmodium, Toxoplasma, Cryptosporidium, Eimeria, Neospora, Theileria, and Babesia are the most pervasive apicomplexans in mammalian hosts (Seeber and Steinfelder, 2016). Four species of Plasmodium, the causative agent of malaria, have long been considered true parasites of humans: P. falciparum, P. malariae, $P$. ovale, and $P$. vivax. Malaria is a life-threatening mosquito-borne disease that inflicted a tremendous burden on many tropical countries (Talapko et al. 2019). In 2018, there were an estimated 228 million cases of malaria occurred globally, of whom around 405,000 succumbed to death (WHO 2019). Various Plasmodium species exhibit different clinical presentations, progression, and anti-malarial resistance patterns. The deadliest species is $P$. falciparum, accountable for the vast majority of the mortality and morbidity associated with malaria infection (Phillips et al. 2017). Quinine derivatives and artemisinin compounds are 
crucial anti-malarial medications. Disappointingly, the emergence and dissemination of resistance against these drugs have thwarted efforts to control human malaria. On top of that, development of a malaria vaccine is technically very challenging because the pathogen has evolved highly effective immune-evasion strategies (Ashley et al. 2018).

Plasmodium berghei, a rodent pathogen, has been frequently used as a model microorganism for human malaria studies (Goodman et al. 2013). In a study carried out by Carter et al. (2013), a 30-min incubation of P. berghei ookinetes with $50 \mu \mathrm{M}$ of melittin culminated in a complete loss of parasite viability. However, melittin $(25 \mu \mathrm{M})$ showed profound toxicity to an Anopheles gambiae cell line (Sua 4.0) after $3 \mathrm{~h}$ of incubation. Notwithstanding this in vitro cytotoxicity, feeding blood containing $50 \mu \mathrm{M}$ of melittin to mosquitos had no significant deleterious effects on either longevity or fecundity over a 10-day period (Carter et al. 2013). One possible explanation for these discrepant findings is that there exist some physiological differences between cultured cells and midgut epithelial cells of mosquitos. For instance, the peritrophic matrix might protect the latter from mechanical and chemical damages (Parish et al. 2011; Lehane 1997).

A promising approach to control Plasmodium transmission is the production of genetically modified vectors (transgenic organisms) that are incapable of malaria transmission (Ogaugwu and Durvasula, 2017). This might be achieved through interference with the malaria mosquito's vectorial capacity to support Plasmodium development (Wang et al. 2017). It has also been suggested that the midgut lumen of anopheline vector can serve as a prime target for relevant interventions since this hostile environment represents a severe bottleneck to parasite transmission (Paton et al. 2019; Wang and Jacobs-Lorena, 2013). A perfect transmission-blocking molecule selected to be expressed in midgut of genetically modified vectors needs to be highly efficacious, soluble, rapid-acting, and resistant to proteolytic degradation while having no negative impact upon both lifespan and reproductive abilities of the mosquito (Carter and Hurd, 2010). Furthermore, the ability of an effector molecule to interrupt parasite transmission can be quantified by infection prevalence and infection intensity (Wu et al. 2015). The former denotes the proportion of mosquitoes harboring at least one oocyst, while the latter implies the number of oocysts per mosquito (Habtewold et al. 2019). In this regard, one study assessed the in vivo effects of several anti-microbial peptides (AMPs) against sporogonic stages of P. berghei when Anopheles stephensi were fed on gametocyte-containing blood supplemented with $50 \mu \mathrm{M}$ of each AMP separately (Carter et al. 2013). Among tested AMPs, melittin was the only effective peptide that significantly diminished parasite prevalence by an average of $10 \%$ and intensity of infection by $68 \%$. Almost similar trends were also evident when melittin was tested against the sporogonic stages of $P$. falciparum (Carter et al. 2013).

Particularly impressive was the recent work in which a streamlined and robust standard membrane feeding assay (SMFA) protocol employing coordinated culturing of Anopheles coluzzii and P. falciparum gametocyte was devised by Habtewold et al. (2019). This SMFA protocol consistently yielded high oocyst intensities and prevalence, hence permitting precise appraisal of the effectiveness of transmission-blocking interventions. Using the above-mentioned protocol, the same authors were able to assess the transmission-blocking potential of six selected AMPs, which had previously been shown to exert antiprotozoan activities towards blood-stage $P$. falciparum (Habtewold et al. 2019). When added to gametocytaemic blood, melittin $(50 \mu \mathrm{M})$ exhibited a significant transmission-blocking activity $(p<0.001)$ in comparison to PBStreated mosquitoes (control). The authors also evaluated the expression of multi-melittin arrays separated through $2 \mathrm{~A}$ autocleavage peptides or a furin cleavage site in transgenic mosquitoes. It is worth mentioning that the processed peptides following the $2 \mathrm{~A}$ or furin cleavage would be expected to have further amino acid residues (Wang et al. 2015; Liu et al. 2017), which might modify the structural and functional properties of the expressed peptides. The experimental data revealed that the presence of additional amino acids in expressed melittin had no substantial negative impact upon its transmission-blocking activity, and indeed could potentiate it, as is the case of melittin with sequence "EENPG" at its C-terminus (Habtewold et al. 2019). Overall, transgenic mosquitoes expressing AMPs may offer opportunities for controlling malaria.

\section{Toxoplasma gondii}

Toxoplasma gondii is an obligate intracellular parasite that infects many warm-blooded animals including birds, mammals, and humans. Like other Apicomplexan parasites, T. gondii uses sophisticated, ingenious strategies to invade their host cells (Francia et al. 2016; Reiling and Dixon, 2019). Felines are known to be the only definitive hosts of the pathogen. Infection usually occurs by consuming undercooked contaminated meat harboring tissue cysts, contacting with infected cat feces, mother-to-child transmission during pregnancy, and through blood transfusion or organ transplantation (Robert-Gangneux and Dardé, 2012). Almost one third of the world's population who are infected with $T$. gondii remain asymptomatic. Nonetheless, a small percentage of these patients, in particular immunodeficient individuals, 
manifest severe disease. In humans, T. gondii may form tissue cysts in muscles, myocardium, brain, and eyes (Flegr et al. 2014). Due to the parasite's fondness for brain and retinal tissue, infections may result in chronic complications such as blindness or neurological abnormalities (Flegr et al. 2014). Although the disease is usually self-limiting, clinically severe or persistent toxoplasmosis can be treated with a combination of drugs such as pyrimethamine and sulfadiazine, which inhibits parasite folate metabolism (Rajapakse et al. 2013). The need for long-term therapy and the risk of relapsing disease may be attributed to the lack of effectiveness of these medications towards T. gondii cysts (Alday and Doggett, 2017).

Anti-protozoan effects of melittin against Toxoplasma gondii have been seldom explored. In one study, for instance, Seeber (2000) employed a method in which the membrane lytic effect of melittin on lac $Z$ transgenic strain of $T$. gondii ( $\mathrm{RH} \beta-1$ ) could be determined by measuring the activity of liberated cytosolic $\beta$-galactosidase into the culture supernatant. The author showed that there was a correlation between $\beta$-galactosidase activity and the number of extracellular $T$. gondii tachyzoites. Incubation of purified extracellular tachyzoites with $1.75 \mu \mathrm{M}$ melittin for $1 \mathrm{~h}$ at $37^{\circ} \mathrm{C}$ led to a noticeable increase in $\beta$-galactosidase release, which was approximately similar to that of $0.25 \%$ Triton X-100 (Seeber 2000). This finding implies that melittin directly eradicates extracellular $T$. gondii tachyzoites through disruption of plasma membrane integrity. Though these results appear promising, further research is required to characterize the anti-protozoan effects of melittin on different developmental forms (i.e. bradyzoites and sporozoites) of the parasite.

\section{Future prospects}

Discovery of venom-derived AMPs has given a renewed impetus to anti-parasitic drug development. Despite potent anti-protozoan effects of melittin, the efficacy of the peptide in animal models should be further scrutinized in future investigations. Pre-clinical studies will confront several challenges such as cytotoxicity, in vivo stability, and routes of administration. We envisage that conjugation of melittin with nanoparticles holds great promise in different biomedical applications. Not only does this approach improve the target-specific delivery of melittin with less cytotoxicity, but it also enhances proteolytic stability of nanoparticle-melittin constructs. Given that melittin and its derivatives can act as cell-penetrating peptides (Hou et al. 2013), they may facilitate small interfering RNA (siRNA) transfection for the purpose of suppressing expression of virulence genes in protozoan pathogens (Fig. 1).
Synergistic interactions between melittin and frequently used antibiotics have previously demonstrated evidence of efficacy against bacterial pathogens (Memariani et al. 2019). The ability to combine melittin with established anti-protozoan drugs bodes well for the future. Melittin even at sub-toxic concentrations may boost therapeutic potential of the current medications. Deployment of DNA microarrays and real-time polymerase chain reaction (PCR) assays to evaluate expression levels of many genes in pathogens after melittin treatment and drug-target identification will surely expand our knowledge with reagard to possible cellular responses induced by the peptide challenge. Furthermore, it deserves emphasis that a melittin-based topical cream or ointment could be propounded as a promising treatment for a wide spectrum of dermal infections, from ringworm (dermatophytosis) and wart to cutaneous leishmaniasis (Fig. 1).

Different bee venom components possess immunostimulatory or immunosuppressive properties, depending on dose, time, and the route of administration. Administration of melittin in combination with conventional vaccines can enhance both cell-mediated and humoral immune responses (Fig. 1). Melittin has been proposed as an adjuvant for leishmaniasis (Eltahir Saeed and Khalil, 2017), hepatitis B (Dezfuli et al. 2014), and tetanus-diphtheria vaccines (Bramwell et al. 2003). Nevertheless, further studies are needed to confirm effectiveness of such vaccines in vivo.

The possibility of controlling arthropod-borne diseases through vector transgenesis has recently garnered popular support and is being actively pursued by a number of research laboratories across the globe (Thomas 2018). These genetically modified invertebrates are capable of hampering parasite development by tissue-specific expression of effector molecules that impair pathogen adhesion to the midgut of vectors or activate biochemical pathways detrimental to survivability of pathogens (Coutinho-Abreu et al. 2010). In the paratransgenic strategy, however, genetically altered symbionts are reintroduced back to the vector where expression of the effectors interferes with pathogen transmission (Hurwitz et al. 2012). Various effectors, including AMPs and highly specific single chain antibodies, have been previously explored for controlling vector-borne diseases (Hurwitz et al. 2012; Giovati et al. 2018). Melittin, alone or in combination with other AMPs, has been nominated for both transgenic and paratransgenic strategies (Fieck et al. 2010; Ogaugwu and Durvasula, 2017). 


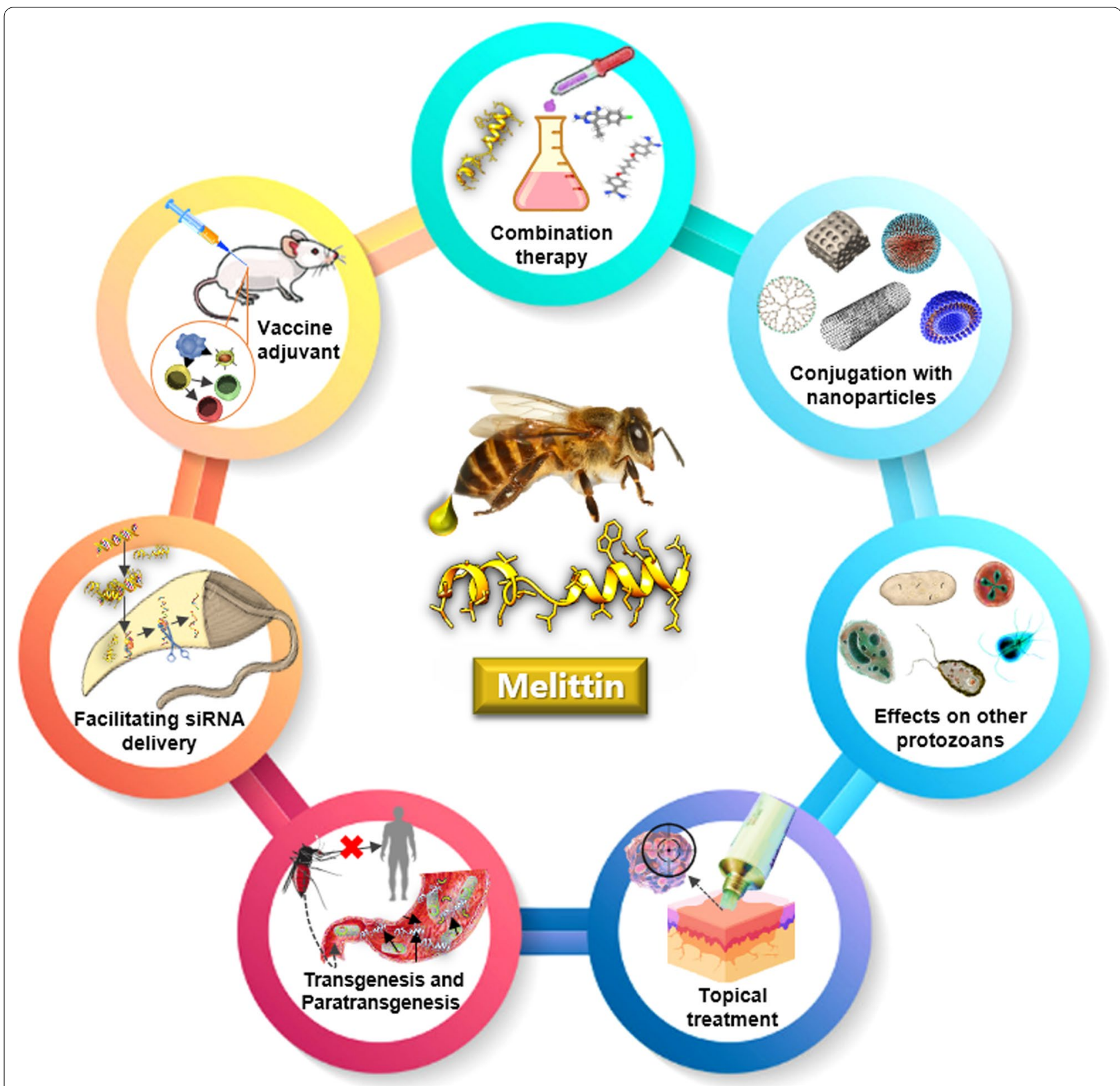

Fig. 1 Potential biomedical applications of melittin for future studies on protozoan diseases

\section{Conclusion}

The growing problem of drug resistance among protozoan pathogens together with the dearth of new anti-parasitic medications poses a major public health challenge. Over the past years, melittin has gained a great deal of attention for its potent anti-protozoan properties. Accumulating evidence suggests that many protozoan parasites such as Leishmania, Plasmodium, Trypanosoma, and Toxoplasma are susceptible to melittin at micromolar concentrations. Melittin obliterates protozoan pathogens by several mechanisms of action including, but not limited to, disruption of cell membrane, destabilization of calcium homeostasis, reduction in mitochondrial membrane potential, and induction of different PCD pathways. Interestingly, production of genetically engineered symbiotic bacteria or transgenic invertebrates expressing melittin appears to be a promising strategy for inhibiting the transmission of vector-borne protozoan diseases. Taken altogether, there is no doubt that melittin 


\section{would herald a new horizon in the fight against microbial pathogens.}

\begin{abstract}
Abbreviations
$\triangle \psi_{m}$ : Mitochondrial membrane potential; ALD: Autoclaved Leishmania donovani; AMPs: Anti-microbial peptides; $\left[\mathrm{Ca}^{2+}\right]$ i: Intracellular concentration of free calcium; $\mathrm{EC}_{50}$ : Median effective concentration; EGTA: Ethylene glycol-bis( $\beta$ aminoethyl ether)- $N, N, N^{\prime}, N^{\prime}$-tetraacetic acid; $H A T$ : Human African trypanosomiasis; $\mathrm{HC}_{50}$ : Median hemolytic concentration; $\mathrm{H}_{2} \mathrm{O}_{2}$ : Hydrogen peroxide; IFN- $\gamma$ : Interferon-ү; IL-10: Interleukin-10; IL-12: Interleukin-12; IP phosphate; $\mathrm{LD}_{50}$ : Half lethal dose; MDC: Monodansylcadaverine; MPMs: Mouse peritoneal macrophages; MTT: 3-(4,5-Dimethylthiazol-2-yl)-2,5-diphenyltetrazolium bromide; NO: Nitric oxide; OBAA: 3-(4-Octadecyl)-benzoylacrylic acid; PCD: Programmed cell death; PI: Propidium iodide; PLA: Phospholipase $A_{2} ;$ Sl: Selectivity index; $L$ LA: Soluble Leishmania donovani antigen; SMFA: Standard membrane feeding assay; TGF- $\beta$ : Transforming growth factor- $\beta$; Th1: T-helper 1; TNF-a: Tumor necrosis factor-a; TUNEL: Terminal deoxynucleotidyl transferase (TDT)-mediated dUTP-biotin nick end-labeling.
\end{abstract}

\section{Acknowledgements}

Not applicable.

\section{Authors' contributions}

$\mathrm{HM}$ contributed to the conception of the study and data collection. MM and HM jointly analyzed the data and wrote the manuscript. MM critically reviewed and edited the manuscript. Both authors read and approved the final manuscript.

\section{Funding}

Not applicable.

\section{Availability of data and materials}

Not applicable.

\section{Declarations}

Ethics approval and consent to participate

Not applicable.

\section{Consent for publication}

Not applicable.

\section{Competing interests}

The authors declare that there are conficts of interest.

\section{Author details}

'Skin Research Center, Shahid Beheshti University of Medical Sciences, Tehran, Iran. ${ }^{2}$ Biotechnology Research Center, Pasteur Institute of Iran, Tehran, Iran. ${ }^{3}$ Department of Pathobiology, School of Public Health, Tehran University of Medical Sciences, Tehran, Iran.

Received: 3 May 2021 Accepted: 5 May 2021

Published online: 13 May 2021

\section{References}

Adade CM, Ribeiro I, Pais J, Souto-Padrón T (2012) Melittin peptide kills Trypanosoma cruzi epimastigotes and trypomastigotes forms by different cell death phenotypes. Toxicon 60:116. https://doi.org/10.1016/j.toxicon. 2012.04.044

Adade CM, Oliveira IRS, Pais JAR, Souto-Padrón T (2013) Melittin peptide kills Trypanosoma cruzi parasites by inducing different cell death pathways. Toxicon 69:227-239. https://doi.org/10.1016/j.toxicon.2013.03.011

Alday PH, Doggett JS (2017) Drugs in development for toxoplasmosis: advances, challenges, and current status. Drug Des Devel Ther 11:273-293. https://doi.org/10.2147/DDDT.S60973
Ashley EA, Phyo AP, Woodrow CJ (2018) Malaria. Lancet 391(10130):1608-1621. https://doi.org/10.1016/S0140-6736(18)30324-6

Azambuja P, Mello CB, D’Escoffier LN, Garcia ES (1989) In vitro cytotoxicity of Rhodnius prolixus hemolytic factor and mellitin towards different trypanosomatids. Braz J Med Biol Res 22(5):597-599

Bacalum M, Radu M (2015) Cationic antimicrobial peptides cytotoxicity on mammalian cells: an analysis using therapeutic Index integrative concept. Int J Pept Res Ther 21:47-55. https://doi.org/10.1007/ s10989-014-9430-z

Benaim G, Paniz-Mondolfi AE, Sordillo EM, Martinez-Sotillo N (2020) Disruption of intracellular calcium homeostasis as a therapeutic target against Trypanosoma cruzi. Front Cell Infect Microbiol 14(10):46. https://doi.org/ 10.3389/fcimb.2020.00046

Bern C (2015) Chagas' Disease. N Engl J Med 373(5):456-466. https://doi.org/ 10.1056/NEJMra1410150

Biederbick A, Kern HF, Elsässer HP (1995) Monodansylcadaverine (MDC) is a specific in vivo marker for autophagic vacuoles. Eur J Cell Biol 66(1):3-14

Black SJ, Mansfield JM (2016) Prospects for vaccination against pathogenic African trypanosomes. Parasite Immunol 38(12):735-743. https://doi. org/10.1111/pim.12387

Bramwell VW, Somavarapu S, Outschoorn I, Alpar HO (2003) Adjuvant action of melittin following intranasal immunisation with tetanus and diphtheria toxoids. J Drug Target 11(8-10):525-530. https://doi.org/10.1080/10611 860410001670080

Bukachi SA, Mumbo AA, Alak ACD, Sebit W, Rumunu J, Biéler S, Ndung'u JM (2018) Knowledge, attitudes and practices about human African trypanosomiasis and their implications in designing intervention strategies for Yei county. South Sudan Plos Negl Trop Dis 12(10):e0006826. https:// doi.org/10.1371/journal.pntd.0006826

Capela R, Moreira R, Lopes F (2019) An overview of drug resistance in protozoal diseases. Int J Mol Sci 20(22):5748. https://doi.org/10.3390/ijms2 0225748

Carpena M, Nuñez-Estevez B, Soria-Lopez A, Simal-Gandara J (2020) Bee venom: an updating review of its bioactive molecules and its health applications. Nutrients 12(11):3360. https://doi.org/10.3390/nu121 13360

Carter V, Hurd H (2010) Choosing anti-Plasmodium molecules for genetically modifying mosquitoes: focus on peptides. Trends Parasitol 26(12):582590. https://doi.org/10.1016/.jpt.2010.07.005

Carter V, Underhill A, Baber I, Sylla L, Baby M, Larget-Thiery I, Zettor A, Bourgouin C, Langel Ü, Faye I, Otvos L, Wade JD, Coulibaly MB, Traore SF, Tripet F, Eggleston P, Hurd H (2013) Killer bee molecules: antimicrobial peptides as effector molecules to target sporogonic stages of Plasmodium. PLoS Pathog 9(11):e1003790. https://doi.org/10.1371/journal. ppat. 1003790

Catisti R, Uyemura SA, Docampo R, Vercesi AE (2000) Calcium mobilization by arachidonic acid in trypanosomatids. Mol Biochem Parasito 105(2):261271. https://doi.org/10.1016/s0166-6851(99)00186-31

Cestari I (2020) Phosphoinositide signaling and regulation in Trypanosoma brucei: Specialized functions in a protozoan pathogen. PLoS Pathog 16(1):e1008167. https://doi.org/10.1371/journal.ppat.1008167

Cornara L, Biagi M, Xiao J, Burlando B (2017) Therapeutic properties of bioactive compounds from different honeybee products. Front Pharmacol 8:412. https://doi.org/10.3389/fphar.2017.00412

Coutinho-Abreu IV, Zhu KY, Ramalho-Ortigao M (2010) Transgenesis and paratransgenesis to control insect-borne diseases: current status and future challenges. Parasitol Int 59(1):1-8. https://doi.org/10.1016/j. parint.2009.10.002

de Paulo MV, Galizzi M, Salto ML, Docampo R, Moreno SNJ (2010) Developmental expression of a Trypanosoma cruzi phosphoinositide-specific phospholipase $\mathrm{C}$ in amastigotes and stimulation of host phosphoinositide hydrolysis. Infect Immun 78(10):4206-4212. https://doi.org/10. 1128/IAI.00473-10

Dempsey CE (1990) The actions of melittin on membranes. Biochim Biophys Acta 1031(2):143-161. https://doi.org/10.1016/0304-4157(90)90006-x

Dezfuli HT, Shahbazzadeh D, Eidi A, Bagheri KP, Pakravan N, Amini S, Aghasadeghi MR, Mahdavi M (2014) Induction of IFN- $\gamma$ cytokine response against hepatitis B surface antigen using melittin. Gastroenterol Hepatol Bed Bench 7(2):108-117 
Díaz-Achirica P, Ubach J, Guinea A, Andreu D, Rivas L (1998) The plasma membrane of Leishmania donovani promastigotes is the main target for CA(1-8)M(1-18), a synthetic cecropin A-melittin hybrid peptide. Biochem J 330(Pt 1):453-460. https://doi.org/10.1042/bj3300453

Dotimas EM, Hider RC (1987) Honeybee venom. Bee World 68:51-70. https:// doi.org/10.1080/0005772X.1987.11098915

Duffy C, Sorolla A, Wang E, Golden E, Woodward E, Davern K, Ho D, Johnstone E, Pfleger K, Redfern A, lyer KS, Baer B, Blancafort P (2020) Honeybee venom and melittin suppress growth factor receptor activation in HER2-enriched and triple-negative breast cancer. NPJ Precis Oncol 4:24. https://doi.org/10.1038/s41698-020-00129-0

Duran-Rehbein GA, Vargas-Zambrano JC, Cuéllar A, Puerta CJ, Gonzalez JM (2014) Mammalian cellular culture models of Trypanosoma cruzi infection: a review of the published literature. Parasite 21:38. https://doi.org/ 10.1051/parasite/2014040

Eltahir Saeed WS, Khalil EAG (2017) Immune response modifying effects of bee venom protein [melittin]/ autoclaved L. donovani complex in CD1 mice: The search for new vaccine adjuvants. J Vaccines Vaccin 8:5. https://doi. org/10.4172/2157-7560.1000372

Fennell JF, Shipman WH, Cole LJ (1967) Antibacterial action of a bee venom fraction (melittin) against a penicillin-resistant Staphylococcus and other microorganisms. USNRDL-TR-67-101. Res Dev Tech Rep 5:1-13

Fieck A, Hurwitz I, Kang AS, Durvasula R (2010) Trypanosoma cruzi: synergistic cytotoxicity of multiple amphipathic anti-microbial peptides to T. cruzi and potential bacterial hosts. Exp Parasitol 125(4):342-327. https://doi. org/10.1016/j.exppara.2010.02.016

Flegr J, Prandota J, Sovičková M, Israili ZH (2014) Toxoplasmosis-a global threat. Correlation of latent toxoplasmosis with specific disease burden in a set of 88 countries. PLoS ONE 9(3):e90203. https://doi.org/10.1371/ journal.pone.0090203

Francia ME, Dubremetz JF, Morrissette NS (2016) Basal body structure and composition in the apicomplexans Toxoplasma and Plasmodium. Cilia 5:3. https://doi.org/10.1186/s13630-016-0025-5

Fumarola L, Spinelli R, Brandonisio O (2004) In vitro assays for evaluation of drug activity against Leishmania spp. Res Microbiol 155(4):224-230. https://doi.org/10.1016/j.resmic.2004.01.001

Giovati L, Ciociola T, Magliani W, Conti S (2018) Antimicrobial peptides with antiprotozoal activity: current state and future perspectives. Future Med Chem 10(22):2569-2572. https://doi.org/10.4155/fmc-2018-0460

Goodman AL, Forbes EK, Williams AR, Douglas AD, de Cassan SC, Bauza K, Biswas S, Dicks MDJ, Llewellyn D, Moore AC, Janse CJ, Franke-Fayard BM, Gilbert SC, Hill AVS, Pleass RJ, Draper SJ (2013) The utility of Plasmodium berghei as a rodent model for anti-merozoite malaria vaccine assessment. Sci Rep 3:1706. https://doi.org/10.1038/srep01706

Habermann E (1972) Bee and wasp venoms. Science 177(4046):314-322. https://doi.org/10.1126/science.177.4046.314

Habtewold T, Tapanelli S, Masters EKG, Hoermann A, Windbichler N, Christophides GK (2019) Streamlined SMFA and mosquito dark-feeding regime significantly improve malaria transmission-blocking assay robustness and sensitivity. Malar J 18(1):24. https://doi.org/10.1186/ s12936-019-2663-8

Hall K, Lee TH, Aguilar MI (2011) The role of electrostatic interactions in the membrane binding of melittin. J Mol Recognit 24(1):108-118. https:// doi.org/10.1002/jmr.1032

Harrison JR, Sarkar S, Hampton S, Riley J, Stojanovski L, Sahlberg C, Appelqvist P, Erath J, Mathan V, Rodriguez A, Kaiser M, Pacanowska DG, Read KD, Johansson NL, Gilbert IH (2020) Discovery and optimization of a compound series active against Trypanosoma cruzi, the causative agent of Chagas disease. J Med Chem 63(6):3066-3089. https://doi.org/10.1021/ acs.jmedchem.9b01852

Hauser RA, Daguio M, Wester D, Hauser M, Kirchman A, Skinkis C (2001) Bee-venom therapy for treating multiple sclerosis: a clinical trial. Altern Complement Ther 7(1):37-45. https://doi.org/10.1089/1076280013 00000714

Hong J, Lu X, Deng Z, Xiao S, Yuan B, Yang K (2019) How Melittin inserts into cell membrane: conformational changes, inter-peptide cooperation, and disturbance on the membrane. Molecules 24(9):1775. https://doi. org/10.3390/molecules24091775

Hou KK, Pan H, Lanza GM, Wickline SA (2013) Melittin derived peptides for nanoparticle based siRNA transfection. Biomaterials 34(12):3110-3119. https://doi.org/10.1016/j.biomaterials.2013.01.037
Hurwitz I, Fieck A, Durvasula R (2012) Antimicrobial peptide delivery strategies: use of recombinant antimicrobial peptides in paratransgenic control systems. Curr Drug Targets 13(9):1173-1180. https://doi.org/10.2174/ 138945012802002366

Jacobs T, Bruhn H, Gaworski I, Fleischer B, Leippe M (2003) NK-Lysin and its shortened analog NK-2 exhibit potent activities against Trypanosoma cruzi. Antimicrob Agents Chemother 47(2):607-613. https://doi.org/10. 1128/AAC.47.2.607-613.2003

Kane MM, Mosser DM (2001) The role of IL-10 in promoting disease progression in Leishmaniasis. J Immunol 166(2):1141-1147. https://doi.org/10. 4049/jimmunol.166.2.1141

Karpiyevich M, Artavanis-Tsakonas K (2020) Ubiquitin-like modifiers: Emerging regulators of protozoan parasites. Biomolecules 10(10):1403. https://doi. org/10.3390/biom10101403

Kim H, Park SY, Lee G (2019) Potential therapeutic applications of bee venom on skin disease and its mechanisms: a literature review. Toxins (basel) 11(7):374. https://doi.org/10.3390/toxins11070374

Knöppel E, Eisenberg D, Wickner W (1979) Interactions of melittin, a preprotein model, with detergents. Biochemistry 18(19):4177-4181. https://doi. org/10.1021/bi00586a021

Kroemer G, Galluzzi L, Vandenabeele P, Abrams J, Alnemri ES, Baehrecke EH, Blagosklonny MV, El-Deiry WS, Golstein P, Green DR, Hengartner M, Knight RA, Kumar S, Lipton SA, Malorni W, Nuñez G, Peter ME, Tschopp J, Yuan J, Piacentini M, Zhivotovsky B, Melino G (2009) Classification of cell death: recommendations of the Nomenclature Committee on Cell Death 2009. Cell Death Differ 16:3-11. https://doi.org/10.1038/cdd. 2008.150

Kyrylkova K, Kyryachenko S, Leid M, Kioussi C (2012) Detection of apoptosis by TUNEL assay. Methods Mol Biol 887:41-47. https://doi.org/10.1007/ 978-1-61779-860-3_5

Lauterwein J, Bösch C, Brown LR, Wüthrich K (1979) Physicochemical studies of the protein-lipid interactions in melittin-containing micelles. Biochim Biophys Acta 556(2):244-264. https://doi.org/10.1016/0005-2736(79) 90046-4

Lee N, Bertholet S, Debrabant A, Muller J, Duncan R, Nakhasi HL (2002) Programmed cell death in the unicellular protozoan parasite Leishmania. Cell Death Differ 9(1):53-64. https://doi.org/10.1038/sj.cdd.4400952

Lee JA, Son MJ, Choi J, Jun JH, Kim JI, Lee MS (2014) Bee venom acupuncture for rheumatoid arthritis: a systematic review of randomised clinical trials. BMJ Open 4(11):e006140. https://doi.org/10.1136/bmjop en-2014-006140

Lehane MJ (1997) Peritrophic matrix structure and function. Annu Rev Entomol 42:525-550. https://doi.org/10.1146/annurev.ento.42.1.525

Liu Z, Chen O, Wall JBJ, Zheng M, Zhou Y, Wang L, Vaseghi HR, Qian L, Liu J (2017) Systematic comparison of 2A peptides for cloning multi-genes in a polycistronic vector. Sci Rep 7:2193. https://doi.org/10.1038/ s41598-017-02460-2

Malvy D, Chappuis F (2011) Sleeping sickness. Clin Microbiol Infect 17(7):986995. https://doi.org/10.1111/j.1469-0691.2011.03536.x

Maulet Y, Brodbeck U, Fulpius BW (1982) Purification from bee venom of melittin devoid of phospholipase $\mathrm{A}_{2}$ contamination. Anal Biochem 127(1):61-67. https://doi.org/10.1016/0003-2697(82)90144-0

Memariani H, Memariani M (2020) Anti-fungal properties and mechanisms of melittin. Appl Microbiol Biotechnol 104(15):6513-6526. https://doi.org/ 10.1007/s00253-020-10701-0

Memariani H, Memariani M, Pourmand MR (2018) Venom-derived peptide Mastoparan-1 eradicates planktonic and biofilm-embedded methicillinresistant Staphylococcus aureus isolates. Microb Pathog 119:72-80. https://doi.org/10.1016/j.micpath.2018.04.008

Memariani H, Memariani M, Shahidi-Dadras M, Nasiri S, Akhavan MM, Moravvej H (2019) Melittin: from honeybees to superbugs. Appl Microbiol Biotechnol 103(8):3265-3276. https://doi.org/10.1007/s00253-019-09698-y

Memariani H, Memariani M, Moravvej H, Shahidi-Dadras M (2020a) Melittin: a venom-derived peptide with promising anti-viral properties. Eur J Clin Microbiol Infect Dis 39(1):5-17. https://doi.org/10.1007/ s10096-019-03674-0

Memariani H, Memariani M, Robati RM, Nasiri S, Abdollahimajd F, Baseri Z, Moravvej H (2020b) Anti-Staphylococcal and cytotoxic activities of the short anti-microbial peptide PVP. World J Microbiol Biotechnol 36(11):174. https://doi.org/10.1007/s11274-020-02948-6 
Menna-Barreto RFS (2019) Cell death pathways in pathogenic trypanosomatids: lessons of (over)kill. Cell Death Dis 10(2):93. https://doi.org/10. 1038/s41419-019-1370-2

Mirzaei A, Maleki M, Masoumi E, Maspi N (2020) A historical review of the role of cytokines involved in leishmaniasis. Cytokine. https://doi.org/10. 1016/j.cyto.2020.155297

Müller J, Hemphill A (2016) Drug target identification in protozoan parasites. Expert Opin Drug Discov 11(8):815-824. https://doi.org/10.1080/17460 441.2016 .1195945

Mutiso JM, Macharia JC, Gicheru MM (2010) A review of adjuvants for Leishmania vaccine candidates. J Biomed Res 24(1):16-25. https://doi.org/10. 1016/S1674-8301(10)60004-8

Neumann W, Habermann E, Amend G (1952) Zur papierelektrophoretischen fraktionierung tierischer gifte. Naturwissenschaften 39(12):286-287. https://doi.org/10.1007/BF00591257

Norman FF, Comeche B, Chamorro S, Pérez-Molina JA, López-Vélez R (2020) Update on the major imported protozoan infections in travelers and migrants. Future Microbiol 15:213-225. https://doi.org/10.2217/ fmb-2019-0212

Ogaugwu CE, Durvasula RV (2017) Developing the arsenal against pest and vector dipterans: inputs of transgenic and paratransgenic biotechnologies. In: Shields VDC (ed) Biological control of pest and vector insects. Rijeka, InTech, pp 325-347

Okwor I, Uzonna JE (2016) Pathways leading to interleukin-12 production and protective immunity in cutaneous leishmaniasis. Cell Immunol 309:32-36. https://doi.org/10.1016/j.cellimm.2016.06.004

Parish LA, Colquhoun DR, Ubaida Mohien C, Lyashkov AE, Graham DR, Dinglasan RR (2011) Ookinete-interacting proteins on the microvillar surface are partitioned into detergent resistant membranes of Anopheles gambiae midguts. J Proteome Res 10:5150-5162. https://doi.org/10. 1021/pr2006268

Paton DG, Childs LM, Itoe MA, Holmdahl IE, Buckee CO, Catteruccia F (2019) Exposing anopheles mosquitoes to antimalarials blocks Plasmodium parasite transmission. Nature 567(7747):239-243. https://doi.org/10. 1038/s41586-019-0973-1

Pereira AV, de Barros G, Pinto EG, Tempone AG, de Oliveira OR, dos Santos LD, Calvi S, Ferreira RS Jr, Pimenta DC, Barraviera B (2016) Melittin induces in vitro death of Leishmania (Leishmania) infantum by triggering the cellular innate immune response. J Venom Anim Toxins Incl Trop Dis 22:1. https://doi.org/10.1186/s40409-016-0055-x

Pérez-Cordero JJ, Lozano JM, Cortés J, Delgado G (2011) Leishmanicidal activity of synthetic antimicrobial peptides in an infection model with human dendritic cells. Peptides 32(4):683-690. https://doi.org/10. 1016/j.peptides.2011.01.011

Phillips MA, Burrows JN, Manyando C, van Huijsduijnen RH, Van Voorhis WC, Wells TNC (2017) Malaria. Nat Rev Dis Primers 3:17050. https://doi.org/ 10.1038/nrdp.2017.50

Piacenza L, Irigoín F, Alvarez MN, Peluffo G, Taylor MC, Kelly JM, Wilkinson SR, Radi R (2007) Mitochondrial superoxide radicals mediate programmed cell death in Trypanosoma cruzi: cytoprotective action of mitochondrial iron superoxide dismutase overexpression. Biochem J 403(2):323-334. https://doi.org/10.1042/BJ20061281

Raghuraman H. Chattopadhyay A (2007) Melittin: a membrane-active peptide with diverse functions. Biosci Rep 27(4-5):189-223. https://doi.org/10. 1007/s10540-006-9030-z

Rajapakse S, Chrishan Shivanthan M, Samaranayake N, Rodrigo C, Deepika Fernando S (2013) Antibiotics for human toxoplasmosis: a systematic review of randomized trials. Pathog Glob Health 107(4):162-169. https://doi.org/10.1179/2047773213Y.0000000094

Reiling SJ, Dixon BR (2019) Toxoplasma gondii: How an Amazonian parasite became an Inuit health issue. Can Commun Dis Rep 45(7-8):183-190. https://doi.org/10.4745/ccdr.v45i78a03

Ridgley EL, Xiong ZH, Ruben L (1999) Reactive oxygen species activate a $\mathrm{Ca}^{2+}$-dependent cell death pathway in the unicellular organism Trypanosoma brucei brucei. Biochem J 340:33-40

Roatt BM, de Oliveira Cardoso JM, De Brito RCF, Coura-Vital W, de Oliveira Aguiar-Soares RD, Reis AB (2020) Recent advances and new strategies on leishmaniasis treatment. Appl Microbiol Biotechnol 104(21):89658977. https://doi.org/10.1007/s00253-020-10856-w
Robert-Gangneux F, Dardé ML (2012) Epidemiology of and diagnostic strategies for toxoplasmosis. Clin Microbiol Rev 25(2):264-296. https://doi. org/10.1128/CMR.05013-11

Ruben L, Akins CD, Haghighat NG, Xue L (1996) Calcium influx in Trypanosoma brucei can be induced by amphiphilic peptides and amines. Mol Biochem Parasitol 81(2):191-200. https://doi.org/10.1016/0166-6851(96) 02707-7

Sbaraglini ML, Vanrell MC, Bellera CL, Benaim G, Carrillo C, Talevi A, Romano PS (2016) Neglected tropical protozoan diseases: drug repositioning as a rational option. Curr Top Med Chem 16(19):2201-2222. https://doi.org/ 10.2174/1568026616666160216154309

Scott P, Trinchieri G (1997) IL-12 as an adjuvant for cell-mediated immunity. Semin Immunol 9(5):285-291. https://doi.org/10.1006/smim.1997.0084

Seeber F (2000) An enzyme-release assay for the assessment of the lytic activities of complement or antimicrobial peptides on extracellular Toxoplasma gondii. J Microbiol Methods 39(3):189-196. https://doi. org/10.1016/s0167-7012(99)00117-7

Seeber F, Steinfelder S (2016) Recent advances in understanding apicomplexan parasites. F1000Res. https://doi.org/10.12688/f1000research. 7924.1

Seo BK, Han K, Kwon O, Jo DJ, Lee JH (2017) Efficacy of bee venom acupuncture for chronic low back pain: a randomized, double-blinded, sham-controlled trial. Toxins (basel) 9(11):361. https://doi.org/10. 3390/toxins9110361

Smirlis D, Duszenko M, Ruiz AJ, Scoulica E, Bastien P, Fasel N, Soteriadou K (2010) Targeting essential pathways in trypanosomatids gives insights into protozoan mechanisms of cell death. Parasit Vectors 17(3):107. https://doi.org/10.1186/1756-3305-3-107

Souza ALA, Faria RX, Calabrese KS, Hardoim DJ, Taniwaki N, Alves LA, De Simone SG (2016) Temporizin and Temporizin-1 peptides as novel candidates for eliminating Trypanosoma cruzi. PLoS ONE 11(7):e0157673. https://doi.org/10.1371/journal.pone.0157673

Steverding D (2017) The history of leishmaniasis. Parasit Vectors 10(1):82. https://doi.org/10.1186/s13071-017-2028-5

Stuart K, Brun R, Croft S, Fairlamb A, Gürtler RE, McKerrow J, Reed S, Tarleton $R$ (2008) Kinetoplastids: related protozoan pathogens, different diseases. J Clin Invest 118(4):1301-1310. https://doi.org/10.1172/ $\mathrm{JCl} 33945$

Suarez C, Lentini G, Ramaswamy R, Maynadier M, Aquilini E, Berry-Sterkers L, Cipriano M, Chen AL, Bradley P, Striepen B, Boulanger MJ, Lebrun M (2019) A lipid-binding protein mediates rhoptry discharge and invasion in Plasmodium falciparum and Toxoplasma gondii parasites. Nat Commun 10(1):4041. https://doi.org/10.1038/s41467-019-11979-z

Talapko J, Škrlec I, Alebić T, Jukić M, Včev A (2019) Malaria: the past and the present. Microorganisms 7(6):179. https://doi.org/10.3390/micro organisms 7060179

Thakur S, Joshi J, Kaur S (2020) Leishmaniasis diagnosis: an update on the use of parasitological, immunological and molecular methods. J Parasit Dis 44(2):253-272. https://doi.org/10.1007/s12639-020-01212-w

Thomas MB (2018) Biological control of human disease vectors: a perspective on challenges and opportunities. Biocontrol 63(1):61-69. https:// doi.org/10.1007/s10526-017-9815-y

Tomiotto-Pellissier F, Bortoleti BTDS, Assolini JP, Gonçalves MD, Carloto ACM, Miranda-Sapla MM, Conchon-Costa I, Bordignon J, Pavanelli WR (2018) Macrophage polarization in Leishmaniasis: broadening horizons. Front Immunol 9:2529. https://doi.org/10.3389/fimmu.2018. 02529

Torres-Guerrero E, Quintanilla-Cedillo MR, Ruiz-Esmenjaud J, Arenas R (2017) Leishmaniasis: a review. F1000Res 6:750. https://doi.org/10.12688/f1000 research.11120.1

Van Assche T, Deschacht M, da Luz RAl, Maes L (2011) Leishmania-macrophage interactions: Insights into the redox biology. Free Radic Biol Med 51:337-351. https://doi.org/10.1016/j.freeradbiomed.2011.05.011

van den Bogaart G, Guzmán JV, Mika JT, Poolman B (2008) On the mechanism of pore formation by melittin. J Biol Chem 283(49):33854-33857. https://doi.org/10.1074/jbc.M805171200

Villalta F, Rachakonda G (2019) Advances in preclinical approaches to Chagas disease drug discovery. Expert Opin Drug Discov 14(11):1161-1174. https://doi.org/10.1080/17460441.2019.1652593 
Vogel H (1981) Incorporation of melittin into phosphatidylcholine bilayers. Study of binding and conformational changes. FEBS Lett 134(1):37-42. https://doi.org/10.1016/0014-5793(81)80545-5

von Stebut E, Belkaid Y, Jakob T, Sacks DL, Udey MC (1998) Uptake of Leishmania major amastigotes results in activation and interleukin 12 release from murine skin-derived dendritic cells: implications for the initiation of anti-Leishmania immunity. J Exp Med 188(8):1547-1552. https://doi. org/10.1084/jem.188.8.1547

Walker AA, Robinson SD, Hamilton BF, Undheim EAB, King GF (2020) Deadly proteomes: a practical guide to proteotranscriptomics of animal venoms. Proteomics 20(17-18):e1900324. https://doi.org/10.1002/pmic. 201900324

Wang S, Jacobs-Lorena M (2013) Genetic approaches to interfere with malaria transmission by vector mosquitoes. Trends Biotechnol 31(3):185-193. https://doi.org/10.1016/j.tibtech.2013.01.001

Wang Y, Wang F, Wang R, Zhao P, Xia Q (2015) 2A self-cleaving peptide-based multi-gene expression system in the silkworm Bombyx mori. Sci Rep 5:16273. https://doi.org/10.1038/srep16273

Wang S, Dos-Santos ALA, Huang W, Liu KC, Oshaghi MA, Wei G, Agre $P$, Jacobs-Lorena M (2017) Driving mosquito refractoriness to
Plasmodium falciparum with engineered symbiotic bacteria. Science 357(6358):1399-1402. https://doi.org/10.1126/science.aan5478 World Health Organization (2019) "The World Malaria Report 2019" at a glance. 2019. https://www.who.int/news-room/feature-stories/detail/worldmalaria-report-2019. Accessed 31 Dec 2020.

Wu Y, Sinden RE, Churcher TS, Tsuboi T, Yusibov V (2015) Development of malaria transmission-blocking vaccines: from concept to product. Adv Parasitol 89:109-152. https://doi.org/10.1016/bs.apar.2015.04.001

Xiong ZH, Ridgley EL, Enis D, Olness F, Ruben L (1997) Selective transfer of calcium from an acidic compartment to the mitochondrion of Trypanosoma brucei. Measurements with targeted aequorins. J Biol Chem 272(49):31022-31028. https://doi.org/10.1074/jbc.272.49.31022

\section{Publisher's Note}

Springer Nature remains neutral with regard to jurisdictional claims in published maps and institutional affiliations.

\section{Submit your manuscript to a SpringerOpen ${ }^{\circ}$ journal and benefit from:}

- Convenient online submission

- Rigorous peer review

- Open access: articles freely available online

- High visibility within the field

- Retaining the copyright to your article

Submit your next manuscript at springeropen.com 